\title{
INFLUENCE OF OTHER LANGUAGES ON THE LEXICAL SYSTEM OF THE INTERNATIONAL ENGLISH LANGUAGE
}

\author{
Abilova Zulfiyya Mammad, PhD student at Odlar Yurdu University, English Language Lecturer at \\ Azerbaijan State Pedagogical University, Azerbaijan, Baku \\ DOI: https://doi.org/10.31435/rsglobal_conf/25112020/7256
}

Abstract. Many natural languages contain a large number of borrowed words, which usually enter the language as the result of cultural-historical, socio-economic and other relations between people. The article is devoted to the English language which, in the process of its historical development, was crossed with the Scandinavian languages and the Norman dialect of the French language. In addition, English almost, throughout its history, had linguistic interaction with Latin, French, Spanish, Russian, German and other languages of the world. This article examines the influence of Latin, French and Scandinavian languages as well as the development of English as the language of international communication.

Keywords: Influence, borrowings, Latin, French, Scandinavian languages, international language, additive multilingualism, subtractive multilingualism.

Введение. Каждый язык уникален и представляет собой основу культуры, мышления, общения, развития, а также через язык передаются традиции, знания и навыки каждого народа. Если изучение языка сопровождается изучением культуры данного языка, тогда обучение становится более продуктивным, т.к. язык является отражением культуры народа, который говорит на этом языке. Язык является звеном, благодаря которому передаются из поколения к поколению культурные ценности, что приводит к их сохранению. В настоящее время язык является не просто орудием коммуникации и познания, а рассматривается в качестве культурного кода нации. Все тонкости культуры народа отражаются в языке, что делает каждый язык- уникальным.

За последние три столетия английский язык распространился по всему миру. Потребность использования его в качестве международного языка постоянно возрастает. В средние века эту позицию занимала латынь, а в качестве международных дипломатических отношений выступал французский язык.

В современном мире английский язык распространён не только, как официальный язык в англоязычных странах, но также является международным языком, на нем издается обширная научная, техническая и художественная литература, он является рабочим языком почти на всех международных конференциях. В настоящее время изучение английского языка в качестве иностранного- широко распространено во всем мире, и потребность в английском языке возросла, как в качестве средства общения, так и в качестве языка современных компьютерных технологий и средств массовой информации.

Стоит отметить, что английский язык смог внести величайший вклад в мировую культуру. Знаменитый английский писатель XVII века Даниэль Дефо про английский язык говорил так: «саксонско-латинско-датско-нормандский наш язык». И для второй половины XVII века это было вполне достаточным и верным выражением, однако в настоящее время сюда следовало бы предписать также индийский, вест-индийский, всемирно-технический и особенно американский языки. [5, с.15]

Основная часть. Как известно, все естественные языки подвергаются большому влиянию со стороны других языков, и английский язык не является исключением. Таких языков огромное множество, однако самыми распространенными можно назвать следующие языки: латинский, французский и конечно же скандинавские языки.

Латинский язык имел в давние времена влияние на многие языки мира, в том числе и на английский, что вполне очевидно для Великобритании, т.к. латинский - являлся языком христианской религии, которую исповедует английский народ, а также древние исторические хроники являются тесной причиной влияния. Английские слова латинского происхождения до сих пор используются в речи, их достаточно много, некоторые из них следующие: street - улица, vice versa - наоборот, et cetera (etc.) - и так далее, pro et contra - за и против, exempli gratia (e.g.) например, verse - стихи, camp - лагерь, school - школа, lion - лев, theatre - театр и многие другие. 
Очень часто именно исторические события, такие как вторжения на инородные земли были причиной влияния одних языков на другие. В случае с британским английским языком, можно назвать скандинавские морские набеги и вторжения, которые безусловно оставили свой след в английском языке, а причиной такого большого влияния на язык были не столько сами вторжения, сколько их дальнейшие поселения на территории Великобритании. Слова, заимствованные после такого рода «поселений», были причиной заимствования именно повседневных слов, которые распространены в английском языке и употребляются и по сей день. По звучанию, скандинавские и английский языки, были чем-то схожи и были понятны для обоих народов, и порой очень сложно определить является ли слово исконно английским либо оно заимствованно со скандинавских языков. Самыми известными заимствованиями в английский язык, являются следующие слова: they, their, them - они, их, их, leg - нога, skin кожа, shirt - рубашка, skirt - юбка, scare - пугать, sly - хитрый, weak - слабый, happy счастливый, knife - нож и так далее [6, с.109-129].

На английский язык также повлиял и французский в силу исторических событий XI века, в связи с необходимостью понятия речи в целом, а также влияние французского являлось вполне естественным, т.к. французский- считался языком элиты. Французские слова можно легко вычислить по нескольким признакам, самые распространенные из которых можно подразделить на следующие группы: слова присущие самим французам, слова с определенными суффиксами и слова имеющие определенные префиксы.

К первой группе относятся слова чисто французского происхождения, хотя их звучания на французском и английском и могут отличаться, но при знании одного из языков они вполне понятны. К таким заимствованным словам можно отнести: café - кафе, ballet - балет, croissant круассан, baguette - багет, renaissance - ренессанс, randezvous - рандеву, genre - жанр и так далее. Данная группа содержит слова, которые имеют непосредственное отношение к Франции. К суффиксам французского происхождения относятся -tion, -ible, -able, -ment, -ous и так далее. Например: tradition - традиция, nation - нация, flexible - гибкий, invisible - невидимый, admirable - восхитительный, miserable - жалкий, tournament - турнир, parliament парламент, famous - известный, marvelous - изумительный и многие другие. К префиксам же французского происхождения относятся dis-, des-, en-например: disturb- нарушать покой, destitution- лишение, entrance-вход и т.д.

Естественно, это далеко не все языки, с которых заимствованы слова в английском языке. В данный список входят многие европейские языки, есть заимствования из славянских, а также и многих других языков. Такое огромное количество слов в языке стало причиной, как внушительных размеров словарей английского языка, так и в некоторой «легкости» в обучении другим языкам.

Как известно, во все времена существовали основные языки мирового общения, к которым относили французский, испанский, русский, а роль основного международного языка обычно присуждалась английскому языку. И какой бы из языков не играл роль международного языка, английский язык - развивался в постоянном контакте с этим языком. Такая особенность позволила английскому языку без трудности приспосабливаться к новым культурам, потребностям и претендовать на роль всемирного языка.

Не каждый язык сможет выполнить роль международного языка, т.к. для этого язык должен обладать рядом особенностей, среди которых основными являются престиж языка, международное положение страны и народа, который является носителем данного языка. Поэтому такая лингвистическая единица, как язык связана с такими экстралингвистическими факторами, как общественно-политические, культурно-исторические и географические показатели.

Основными признаками экспансии английского языка можно назвать тот факт, что в настоящее время, английский язык преподается в разных странах мира на различных этапах образования, а также то, что он является рабочим языком в различных международных организациях. Существует условно три группы англоговорящих людей - носители языка; говорящие, для которых английский язык является вторым языком; говорящие, которые изучают английский язык в качестве иностранного. Естественно, носители языка составляют основную категорию говорящих, однако экспансию английского языка определяют представители двух последних групп.

Изучающие английский, или тот или иной язык, могут в последствии быть обладателями аддитивного или субтрактивного многоязычия. Под аддитивным многоязычием 
понимается явление, при котором индивид основательно изучает иностранный для него язык, понимает и принимает культуру данного языка, что в итоге приводит к эффективному использованию нового изученного языка, однако при этом не вытесняя и не забывая правила использования своего родного языка, а также сохраняя уважительное отношение к культуре данного языка. Такой подход к обучению носит вполне позитивный характер. В средних школах Азербайджанской Республике помимо родного языка, в школах изучаются один или несколько иностранных языков, таких как английский, французский, немецкий или русский языки. При этом у школьников формируется аддитивное многоязычие, т.к. наряду с новым изучаемым иностранным языком, в их программе также есть и свой родной- азербайджанский язык. Такой подход к изучению языков имеет положительное влияние, формируя у учащихся интерес и уважение к другому языку, соответственно также и к другой культуре и народу, при этом не теряя уважения к своему языку и культуре.

Однако в отличии от аддитивного многоязычия, субтрактивное многоязычие при изучении индивидом нового для него языка, усваивая данный язык и принимая его культуру вытесняет родной язык из использования, что приводит также и к отрицательному отношению к культуре данного языка и новоизученный язык занимает место доминирующего языка. Примерами могут служить языки с наименьшим количеством носителей, где в основном, новое поколение изучая международные языки для собственного развития или для продвижения в работе или учебе, или при переезде в другую страну, изучая новый язык перестают говорить на своем родном языке, забывать и не использовать его, что приводит к потере языка, а также и культуры данного языка. Такое многоязычие носит субтрактивный характер.

Выводы. Из всего вышесказанного можно прийти к выводу, что, как и во многих языках, так и в английском языке содержится много заимствованных слов. В ходе английской истории сотни и даже тысячи слов переходили из одного языка в другой, в основном, через постоянные нашествия захватчиков. Однако, в том, что язык содержит много заимствованных слов, имеются также и положительные стороны. В ходе данного процесса обогащается словарный запас языка, появляются новые элементы для словообразования, как в случае с суффиксами и префиксами взятыми из французского языка, а также изучение других языков, из которых были заимствованы слова становится намного проще. Причина большого количества иноязычных слов в английском языке объясняется историческим развитием данного языка, неоднократными завоеваниями Британских островов, а также культура и торговля.

Говоря же об экспансии английского языка на современном этапе, то это вполне оправдано. Английский язык распространен во всем мире, существует потребность в нем, как в международном языке и средстве общения. Как известно, мир находится в процессе глобализации, что приводит к необходимости использования глобального языка, который может связать людей по всему миру независимо от того, какой язык является им родным. На современном этапе, на роль глобального языка претендует именно английский язык, т.к. является основным языком, как средств массовой информации, бизнеса, так и языком современной культуры, языком образования и обязательным языком для изучения в различных учебных заведениях во многих странах мира.

\section{ЛИТЕРАТУРА}

1. Aronin, L., Singleton D. Multilingualism. John Benjamins Publishing, 2012, 230 p.

2. Perspective on language. An Anthology. Edited by John A. Rycenga, Joseph Schwartz. The Ronald Press Company, New York 1963, $356 \mathrm{p}$.

3. Арбекова, Т.И. Английский без ошибок. Correct English for Everyday Use, 2-е изд., испр. и доп. М.: Высшая школа, 1990, 222 с.

4. Беликов, В., Крысин Л. Социолингвистика. Учебник для вузов. М.: Рос. гос. гуманит. ун-т, 2001, 315 с.

5. Брегг, М. Приключения английского языка. Москва, 2013, 418 с.

6. Бруннер, К. История английского языка, Т II. Из-во Иностранной литературы, М.,1956, 323 с.

7. Тулинов, В. Язык мой- друг мой. Минск «Мэджик», 2011, 104 с. 